Man and Nature

L'homme et la nature

\title{
Cinderella or Bluebeard: The Double Plot of Evelina
}

\section{Kenneth W. Graham}

Volume 5, 1986

URI : https://id.erudit.org/iderudit/1011854ar

DOI : https://doi.org/10.7202/1011854ar

Aller au sommaire du numéro

Éditeur(s)

Canadian Society for Eighteenth-Century Studies / Société canadienne d'étude du dix-huitième siècle

ISSN

0824-3298 (imprimé)

1927-8810 (numérique)

Découvrir la revue

Citer cet article

Graham, K. W. (1986). Cinderella or Bluebeard: The Double Plot of Evelina. Man and Nature / L'homme et la nature, 5, 85-98. https://doi.org/10.7202/1011854ar

Copyright (c) Canadian Society for Eighteenth-Century Studies / Sociéte canadienne d'étude du dix-huitième siècle, 1986
Ce document est protégé par la loi sur le droit d'auteur. L'utilisation des services d'Érudit (y compris la reproduction) est assujettie à sa politique d'utilisation que vous pouvez consulter en ligne.

https://apropos.erudit.org/fr/usagers/politique-dutilisation/ 


\section{Cinderella or Bluebeard: The Double Plot of Evelina}

A number of exciting and perceptive recent examinations of eighteenthcentury woman are encouraging reassessments of traditional interpretations of literature. Of special note are Mary Poovey's account of the strains and anxieties entailed in living up to the eighteenth-century standard of a 'Proper Lady'; ${ }^{1}$ Nancy K. Miller's discussion of euphoric and disphoric plots as eighteenth-century heroines experience integration or alienation on entering society; ${ }^{2}$ and Mary Jacobus's richly incoherent account of woman traditionally torn between suffering and desire in the introductory chapter of Women Writing and Writing about Women. Mary Jacobus includes that seething reference to the prison of sensibility created by patriarchy to contain women. ${ }^{3}$ In much of this writing, eighteenth-century woman is presented in terms of polarities: euphoricdisphoric, integration-alienation, desire-suffering, freedom-submission.

A binary shape informs the interpretation of Evelina presented in this essay. The paradigm that best expresses the patterns of obligation and entrapment that regulated the lives of eighteenth-century ladies is the double hook (with homage to Sheilagh Watson). The two central virtues expected of ladies were modesty and delicacy, and each virtue spawned a series of double hooks: an approved manifestation of the virtue as well as a necessary subversive or destructive concomitant. Thus a manifestation of delicacy is innocence, but its destructive concomitant is ignorance, or at least credulity. ${ }^{4}$ An approved characteristic of modesty is silence, but 
an accompanying condition is stifled or frustrated utterance. Delicacy involves a becoming dependency on parents and husbands, but the double hook of dependency is vulnerability, vulnerability to adventurers, rakes, and inadequate parents. The double hook paradigm represents also the counterpoint of text and subtext as proper lady writers acknowledge overtly the claims of social convention but covertly the related dangers. Fanny Burney's account of Evelina and her mother expresses the double hook of woman's entrapment in the conventional virtues of a cruel age when woman's service to the requirements of sensibility too often entails the destruction of self.

A startling view of the relations between the sexes in the late eighteenth century is offered in the influential courtesy book by John Gregory, A Father's Legacy to his Daughters, a book of guidance with which, according to Joyce Hemlow, Fanny Burney was famililar in $1778 .{ }^{5}$ In an introductory passage Gregory observes of his book

... you will hear, at least for once in your lives, the genuine sentiments of a man who has no interest in flattering or deceiving you. ${ }^{6}$

That 'at least for once in your lives' is Gregory's view of the state of communications between sexes. A widower, he feels obliged to prepare his daughters for life in a world where the frequent and, indeed, customary motives for men's attentions to women are flattery and deception. He regrets this lack of sincerity, but he accepts it as customary in manwoman relationships. His opininon is shared by two contrasting yet perceptive social commentators of the time. To Mary Wollstonecraft's ears, the passage rings with 'mournful truth,' and she castigates 'the cold unmeaning intercourse of gallantry' 7 and the various heartless devices employed by men to render women wretched. From an opposed conception of the nature of woman, Lord Chesterfield recommends the very deception that Wollstonecraft attacks.

It is ... absolutely necessary to manage, please and flatter them; and never to discover the least marks of contempt ... A man of sense only trifles with them, plays with them, humours and flatters them ... he neither consults them about, nor trusts them with, serious matters ... ${ }^{8}$

From their differing perspectives, the comments of Wollstonecraft and Chesterfield acknowledge as normal a contempt for women that makes them trifles and playthings and denies them full humanity. Dr. Gregory has in mind this alarming male attitude as he seeks to guide his daughters through the labyrinths of social living. He returns repeatedly to their 
need to maintain womanly delicacy and modesty in a list of hazards that includes the 'uncontrouled licence of men,' and 'the dissipation in ... present manners. ${ }^{\prime 9}$ Recognizing that men and manners constitute a considerable threat to women, that delicacy and modesty are often difficult to maintain amidst strong counter-encouragements, and that even when maintained they do not offer always adequate defences, Dr. Gregory encourages 'a compassionate sympathy to unfortunate women, especially to those who are rendered so by the villainy of men. ${ }^{10}$ Ruined women are sad expectations in Dr. Gregory's world.

Fanny Burney's first published novel has the full title, Evelina or the History of a Young Lady's Entrance into the World. That 'World' is Dr. Gregory's world, a place of active and latent threat to women. Of active threat are the economic and glandular imperatives of men that make women objects of desire at the same time that they are objects of contempt. Of latent threat is the weight of social expectation that defines ladies in terms of passive virtues like Gregory's repeated favourites, modesty and delicacy, a definition that leaves women little scope for contending with the threats around them. To underline liabilities in a woman's life, Fanny Burney presents two stories of violence and betrayal centred on two young ladies entering a corrupt and vicious world for which their social conditionings have not equipped them.

This interpretation may not be the familiar one that treats Evelina as a comedy of manners and as a sensitive portrayal (before Jane Austen) of the intensitites of female mortification. ${ }^{11}$ The tendency to treat Burney as a precursor of Austen has blinded readers and commentators to the fact that Burney's fictional world is much harsher than Austen's. The exclusively comic interpretation is not the fault of Burney who provided her novel with an artful double plot that expresses some serious realities beneath comic surfaces. The narrative recounts the similar histories of the entrance into the world of Evelina and her mother. The encounter with the world results in disaster and death for the mother and to success and triumph for the daughter. The contrasting fates of mother and daughter reveal the vulnerability of a young lady in an environment superficially well-regulated but at core a social and moral wilderness. Evelina's story is patterned on the outline of her mother's to demonstrate a young woman's perils in a society that esteems manners but slights morals.

The story of Caroline, the mother, frames the narrative of Evelina. The Caroline plot is introduced in the first two letters of this epistolary novel and concludes with a deathbed letter recounted near the end when Evelina is about to achieve recognition, wealth, and married happiness - everything that was denied to her mother. The history of Caroline 
begins in pastoral security under the guardianship of Mr. Villars and well removed from her coarse and vulgar mother living in Paris and married to a Monsieur Duval. When Caroline is eighteen, Mme. Duval calls her to Paris where she employs threats and violence to coerce Caroline into marrying one of her second husband's nephews. The intensity of Caroline's plight is reflected in the rashness of her attempted solution. Friendless, in an environment doubly alien by being both urban and foreign, subject to the tyrannies of an ignorant mother, Caroline turns to the only solution that her delicacy and modesty permit and gambles on marriage to escape an intolerable situation. Unfortunately she changes only the terms of her subjection and places herself in the power of a man apparently ready to use to his advantage her desperate isolation. Sir John Belmont marries her in an unwitnessed ceremony, and, when Caroline is disinherited by her vindictive mother, in an act of astonishing wickedness he burns the marriage certificate and repudiates the match. Caroline returns to Mr. Villars but does not survive the birth of her daughter, Evelina. The mother is victim of two forms of violence. Mme. Duval's is the violence of a parental authority whose purposes, because of differences in class and sensibility, are inimical to the daughter. Sir John Belmont manifests a male callousness that regards women as sources of income and as sexual playthings. Caroline's vulnerability to the most common sources of violence experienced by young women, parental and spousal, precipitates the beginning and the end of her catastrophe. The mother creates the vulnerability and Sir John capitalizes on it.

The thematic coherence of this account of a young woman's life as bracketed by violence demonstrates the care that Fanny Burney took in structuring her subplot. Indeed, the narrative art devoted to the presentation of Caroline's experience of the world suggests its importance in the central narrative of Evelina, and reminds us that 'The History of Caroline Evelyn' had an independent narrative life before Evelina was written. It was one of a number of works created by Fanny Burney during her early adolescence and burnt by her on her fifteenth birthday. ${ }^{12}$ Thus the history of Evelina was born from a fully and richly conceived history of Caroline. Much of the narrative and thematic complexity of Evelina results from the intertwining of two plots, both developed in considerable detail and both addressing the problem of woman's defences in a violent age.

When Evelina makes her entrance into the world, she too experiences the perplexity and violence that destroyed her mother. At the age of seventeen Evelina leaves the indulgent care of Mr. Villars and is plunged into a fashionable city life for which her upbringing has not well 
prepared her. Like her mother, Evelina becomes subject to Mme. Duval and must endure her match-making, her violent temper, her threats, and her authority as her closest living acknowledged relative. She is threatened as well by male aggression in a variety of forms. The fate of the mother forms a silent commentary on Evelina's choices and the dangers to her happiness. At a particular point their fates differ, in part because Evelina has the prudence to employ more active defences than delicacy and modesty to protect herself in a vicious world and in part because she has the luck to capture the affections of a worthy man.

The contrast between Evelina's active disposition and her mother's passive one may express a subtle criticism of notions of woman that Dr. Gregory's authoritative book of advice represents. Gregory's Legacy inculcates a narrow concept of womanliness in which the qualities of modesty and delicacy are paramount. For Gregory, modesty involves reserve and silence in public behaviour and a 'native dignity ... which is your natural protection from the familiarities of men.' ${ }^{13}$ Delicacy is related to modesty in Gregory's book of advice although it seems to signal a context of sexuality. Delicacy reveals itself in blushes, in uneasiness 'even at the gaze of admiration.' Delicacy is threatened by too strong a sense of humour, by untoward mirth when dancing, by risqué conversations, and by most English comedies. With an insidious persuasiveness that repeatedly holds up their dead mother as a sterling example of the qualities he is seeking to foster, Gregory recommends to his daughters the guidance of the imagination and 'a warm, open and ingenuous heart' but does not encourage intellectual pursuits and learning: 'keep it a profound secret, especially from the men.' In many ways a puzzling work, it imposes a Hobbesian realism on its assessment of men but leaves women with no more than the most passive defences against male wolfishness. Indeed, its use of the example of a dead mother conscripts the cooperation of guilt and anxiety to enforce the book's lessons.

Fanny Burney never recorded an opinion of Gregory's book, ${ }^{14}$ but the evidence of Evelina suggests that, for the most part, she accepted his strictures. Evelina behaves with the delicacy and modesty that Gregory commends. She is shy about her own beauty and maintains a quiet dignity which may at times protect her from male familiarity. Evelina reflects Gregory in her discomfort at a performance of Congreve's Love for Love: it was so extremely indelicate that Miss Mirvan and I were perpetually out of countenance'(78). Gregory had written: 'there are few English comedies a lady can see, without a shock to delicacy.' ${ }^{\prime 15}$ An important similarity between the two works introduces at the same time an important difference. Both works have frequent recourse to the example of a dead mother, but with Gregory, the mother's example is to be followed, 
while in Evelina it must be rejected if the daughter is not to share the mother's fate and become a passive victim of male arrogance.

One of Evelina's adventures on an evening at the opera exemplifies the closeness of the parallel between mother and daughter, and demonstrates the liabilities of Gregory's standards of womanly conduct and the need for an active disposition. Evelina has planned to accompany the Mirvans and has dressed accordingly for the fashionable stalls (or pit) of the opera house. While dressing she has to refuse the unexpected invitation of the Branghton girls who are clearly attired for a less formal part of the house. Her grandmother appears and in a violent rage demands that Evelina accompany her cousins. The result for Evelina is a series of humiliations. The Branghtons are ignorant of opera decorums: they take seats in an unfashionable balcony of the theatre for which Evelina is wildly overdressed; they complain about costs; they make jejune comments during the performance. When at the end she is approached by Sir Clement Willoughby, she is anxious to avoid his making the acquaintance of her low connections. She intercepts him, and with the excuse that it will reduce crowding in the coach, she agrees to let him conduct her to the Mirvans to return home with them. Of course the Mirvans have already departed and Sir Clement conducts her to his coach instead.

Thus Caroline's history seems about to be repeated by Evelina. To avoid Mme. Duval's tactless authority, Evelina imprudently makes herself subject to the attentions of a rake. Sir Clement arranges for his coach to take them to an unknown part of the city while he flirts with the ideas of seduction and abduction, prepared to take his cue from the reactions of his passenger. Had Evelina offered even the encouragement of passiveness and relied solely on delicacy and modesty to protect her, Sir Clement might have been more forceful in his attentions. But she replies to his overtures with direct and angry rejection, and when she sees that he has taken her out of her way, she tries to throw herself out of the moving coach. When a horrified Sir Clement prevents her, she makes ready to shout for help to the first passerby that appears. Her very vehemence frightens him and he orders his coach to proceed directly to Evelina's lodgings.

Sir Clement is the second plot's parallel to Sir John Belmont, the destroyer of Caroline. Both are examples of male opportunism, although Sir Clement appears to lack the calculated savagery of Sir John Belmont. I say 'appears' because Evelina never gives him the opportunity to do his worst. At their first encounter at the ridotto, his persistent badgering when she will not dance with him, a stranger, reduces her to tears. As her experience of the world increases, she becomes more self-possessed in her dealings with him. He continues to force himself upon her but the coach 
incident represents a turning-point in their relationship and never again does she lose control of herself or of Sir Clement. His every attempt to take advantage of her is repulsed with forthright eloquence that holds up to view the contrast between his pretensions to chivalry and his true behaviour. As the novel progresses, her self-respect and fluent candour gain her ascendency over him. By the time of his final exit from the novel, the erstwhile self-confident Sir Clement, his emotions confused by admiration for Evelina and jealousy for Lord Orville, is reduced to distress and agitation. It is remarkable victory attained against odds from a position of weakness.

Sir Clement is a representative of a world of privilege and insensitivity to which Evelina was born vulnerable. Throughout her dealings with Sir Clement she has had to conceal a real uncertainty and anxiety beneath an apparent self-possession. What makes Sir Clement an especial threat to her is not only an impudent confidence based on his masculinity, but a self-assurance based on class that Evelina does not have and must strenuously feign. Legally, without the acknowledgment of Sir John Belmont, Evelina is a bastard. What has been interpreted by unkind critics as snobbishness ${ }^{16}$ is Evelina's meticulous maintenance of a genteel status. It is not only that her associations and education from birth make becoming the city wife of a Branghton or a Smith repugnant to her, but that any loss of status would make her more vulnerable to men like Sir Clement. To be reduced to one of Dr. Gregory's 'unfortunate women,' to decline into uncertain dependency as Sir Clement's mistress, is a dreadful possibility for Evelina in this environment.

By entering his carriage after the opera, Evelina is being prudently imprudent. She is desperate to deter any further contact between Madame Duval and Sir Clement who has already seen Evelina subject to the old lady's authority. The obvious contrast in behaviour and sensibility between the older and younger woman must make him curious of their relationship and of Evelina's birth. His suspicions would be heightened on hearing the indiscreetly ambiguous phrasing of Madame Duval's earlier introduction of Evelina to the Branghtons: '... my poor daughter Caroline had this child after she ran away from me' (68). Evelina confesses also that she drew Sir Clement away because she did not wish him 'to hear Miss Branghton call me cousin' (94). In her perceptive article, Toby Olshin discusses the importance of birth and family in Evelina but she does not lay sufficient stress on the sources and consequences of Evelina's equivocal birth. It is a subject of recurring anxiety to Evelina for good reason. Evelina is well aware that her obscure birth resulted from a form of male violence perpetrated upon a near-helpless woman and may certainly result in further violence directed at Evelina herself who, lack- 
ing the protection of legitimacy, is even more vulnerable than her mother. Professor Olshin accuses Evelina of moral shallowness in her lack of charity towards her grandmother, yet her coolness to Madame Duval, like her tart snobbishness towards the Branghtons and $\mathrm{Mr}$. Smith, are consistent with her attitudes towards anyone who would endanger her status by revealing its ambiguities.

That acute anxieties based on class consciousness are the source of her dislike of her low relatives is suggested in the contrasting example of her attitudes to her father. Evelina has every cause to hate Sir John Belmont whose villainy destroyed her mother's 'peace, reputation, and life' (126) and blighted her own young life with the taint of an irregular birth. Yet, barring one interesting exception, Evelina exhibits a most unexpected devotion towards him. When Lady Howard dispatches a letter that may result in his acknowledgment of Evelina, she refers to her father as the man 'who has the natural claim to that dear title; a title, which to write, mention, or think of, fills my whole soul with filial tenderness' (130). One might argue that Evelina's passionate piety is directed towards the title rather than the man, yet we have every reason to believe that, injustice to the mother forgotten, both the title and the man will enjoy the warm overflow of daughterly affection. Here we find none of the cold dutifulness and restrained embarrassment that characterizes Evelina's deportment towards her only other close relative, her grandmother. The reason for the contrast seems clear: with more reason to dislike the father than the grandmother, Evelina rejects the grandmother as a threat to her status, and embraces the father as her only source of legitimacy.

The link between Evelina's filial tenderness and her undiscriminating hunger for legitimacy is developed in two consequent episodes. When Sir John Belmont responds to Lady Howard's overture with a witty and derisive rejection of Evelina's pretensions to relationship, while not quite happily consigning him to hell, Evelina is prepared to contemplate the anguish he is hoarding up for time to come' (159). When recognition is withheld, so is filial tenderness. This lapse from exemplary piety is forgotten towards the end of the novel when Sir John agrees to see her and she longs for the moment when she can prostrate herself 'at the feet of the nearest, the most reverenced of all relations, whom my heart yearns to know, and longs to love!' (370) The superlatives place her father above even her mother in her order of regard, but if her sense of justice may be awry her assessment of advantage cannot be faulted.

Evelina lives in a world where benefits are gained only if woman has the wit to distinguish a profitable submission from an unprofitable one. If she is to sacrifice herself to the uncertainties of marriage, it will be on the most advantageous terms. With sensitivities vulnerable to violence 
and vehemence, Evelina had been overwhelmed by her grandmother's authority in the first half_of the novel. Yet once the grandmother insists on a marriage to young Branghton with its myriad disadvantages, Evelina, with firmness unshakeable, refuses. She will not submit her life to her grandmother's authority. Vehement self-respect and the determined maintenance of status are necessary in a social world in which men's customary attitudes to women are wolfish and contemptuous. Mr. Branghton encourages misogyny in his son in comments on women's irrationality (90). At a higher social level Lord Merton is capable of this brutal comment: 'I don't know what the devil a woman lives for after thirty: she is only in other folks away. ${ }^{17}$ The most misogynistic men are the most in favour of passive virtues in women. Captain Mirvan rudely silences his daughter when she is invited to present an independent opinion (109). Mr. Lovel expresses 'an insuperable aversion to strength, either of body or mind, in a female,' and Lord Merton echoes his sentiments: 'a woman wants nothing to recommend her but her beauty and good nature; in every thing else she is either impertinent or unnatural' (361). Those most in favour of woman's weaknesses are those most likely to take advantage of it. Perceptive to such attitudes, Evelina will not display weakness that would make her vulnerable to the callousness surrounding her.

The novel demonstrates that delicacy and modesty are not adequate defences where young women, particularly those without the protections of male relatives and class position, are regarded as legitimate prey. With Mr. Lovel, the first man Evelina meets in London while perplexed by the intricacies of urban social life, the tactics for asserting male dominance extend to a malicious browbeating. He is eager to humiliate a clearly inexperienced seventeen-year old at her first ball because she has innocently refused his complacent offer to dance and then unknowingly broken decorum by dancing with someone else. He is prepared thereafter to take every opportunity to remind Evelina, and those with her, of her ignorance of sophisticated city manners. Fanny Burney arranges her narrative so that, of the first three men Evelina meets in the city, two seek advantages from her inexperience that could lead to misfortune and even ruin. Sir Clement would seduce her and Lovel would see her publicly humiliated. Only Lord Orville seeks to protect her. The odds are against her. Male wolfishness, in combination with Evelina's inexperience of city life, seems destined to conquer her determined self-respect.

Evelina's experiences with men are examples of a wide-spread violence in Burney's setting, a violence significantly centred on conflict between the sexes in which male rapaciousness is an assumed norm. Intersexual turbulence is exemplified and exaggerated by Capt. Mirvan and Mme. 
Duval, whose dissensions take physical forms. On their second meeting Mme. Duval knocks a candle out of the captain's hand and spits in his face. He in turn takes her by the shoulders and shakes her. On another occasion he masquerades as a highway robber to tie her and fling her into a ditch. The broils of the captain and Mme. Duval are portrayed as rough farce, but their boisterous behaviour calls attention to a more general social disorder that darkens Burney's setting. Characters are pushed into mud, Lovel is attacked by a monkey, two old ladies are matched in a near-fatal footrace and all such scenes are portrayed with a sense of the grotesque that makes the events not only ludicrous but distressing. A disturbing proportion of the characters in Evelina are prepared to take advantage of superior wealth, superior status and superior skill at arms to inflict humiliations on others. We are reminded of the socially-sanctioned terminus of violence on at least four occasions when disputes threaten to result in duels. By underlining such reminders with references to Caroline's fate, the narrative undercuts the ludicrous to draw attention to the fact this society's lack of humanity can ultimately lead to death.

While Evelina learns to deal with some of the more obvious and innocuous male attempts on her, she is genuinely afraid of overt male compulsion for which she has little defence. Too often male sexual passions operate in concert with her society's tolerance of violence to threaten both her physical and her social well-being. A variety of men physically seize her, and she is rightly terrified when such encounters take place in private, as in Sir Clement's coach, or in darkness, as at Marylebone Gardens when she falls into the hands of a young officer, or at Vauxhall when her way is blocked by a party of riotous young men and, fleeing from them, she has her hand caught by a group of men of a higher class who take her, ominously, for an actress. On that occasion she is rescued by Sir Clement who, in turn, catches her hand and draws her into a dark alley of the park to take advantage of her fear, distraction and gratitude for his assistance. When she recovers her presence of mind she has to push him physically away from her and chastize him for his unchivalric behaviour of offering insolence when she had claimed protection. Her directness and her assumption of a genteel status keep Sir Clement off balance. At Mrs. Beaumont's however, she cannot avoid the drunken attentions of Lord Merton and, seeing Lord Orville about to conduct his sister away from Lord Merton's company, Evelina, with a cri de coeur exclaims the vulnerability of a woman and orphan and sums up her experience with the male sex:

"Would to Heaven," cried I, frightened to see how much Lord Merton was in li- 
quor, "that I too had a brother! - and then I should not be exposed to such treatment!"

She pronounces the death of chivalry:

"... in a situation that calls for protection, to meet only with mortifications ..." (315)

So general is her experience of gentlemen who use courtliness as an aid but never a restraint to seduction that when Lord Orville kneels to propose to her, she thinks at first that he is mocking her.

If Evelina succeeds in overcoming the latent liability of society's conception of women, she can never rest secure of the active liability of male attitudes and behaviour. The world projected by the nervous sensibilities of the twenty-four year old Fanny Burney is certainly a man's world. Daddy Crisp had warned her that men are 'design'd to be - Animals of Prey ... violent, and uncontroulable. ${ }^{18}$ All of Evelina's experiences of the delights of the superficial world of balls, plays, excursions and entertainments are touched by anxiety with her recognition of the underground world where male passions seethe and bubble, ever on the point of exploding in destructive violence. Her parentage and birth are constant reminders of that dark reality. Frustrated of a satisfactory marriage-settlement, her father had angrily destroyed his marriage and ultimately his wife. To contend with that world without father, mother or even the assurance of legitimacy, Evelina has to control those tender sensibilities that the culture encourages in its young women and assert her wit and understanding. One of the few men to appreciate these qualities in a woman, Lord Orville finds her 'informed, sensible, and intelligent' (347). In addition, the reader discovers in Evelina a growing toughness and resiliency whenever her status or morals are threatened. While her intelligence and strength of will distinguish her from her mother, they are not enough to separate her from her mother's fate. In a world where any private place might face her with the irreversible attentions of an uninhibited philanderer, Evelina is lucky to avoid all the snares and to love and be loved by a man as sensitive and virtuous as Lord Orville. The real source of the difference between Evelina's fate and her mother's is the difference between Lord Orville and Sir John Belmont.

In her perceptive study, Romantics, Rebels, and Reactionaries, Marilyn Butler reflects received opinion when she casually includes Evelina in a list of novels that base their plots on the Cinderella myth. ${ }^{19}$ Superficially the observation is just: in the course of her narrative Evelina acquires independent wealth, legitimacy as the recognized 
daughter of a baronet, and a soaring social elevation with marriage to an earl. What the observation ignores is the significant second plot that counters the fairy-tale simplifications of the Cinderella story and directs attention to violent and vicious social realities. While Evelina defends herself actively from seductions and improves on her mother's example by resisting social encouragements to be passive, the double perspective of the novel reminds us that the comic outcome of Evelina's story may be conventional, but it is unrealistic. The second plot offers a counter-myth based on the novel's perception of relations between the sexes in a social setting characterized by an underlying violence. The novel pairs men and women in courtship and marriage, but apart from Evelina's, the sad reality is that there are no happy or potentially happy marriages in the novel. Capt. Mirvan's returns from the sea bring rudeness, domineering, insensitivity, vulgarity and humiliation to his wife. Evelina's grandfather's marriage brought him shame, bitterness and an early death. Her father abandoned her mother to disgrace and death. The two relationships likely to lead to marriage in the novel hold out no promise for future happiness. Mr. Brown is an indifferent suitor to Polly Branghton as is Lord Merton, whose real passions are for drinking, wenching and gambling, to Lady Louisa. It is the experience of Evelina's mother and of most married people to awake one morning to find themselves married to a monster. The double plot suggests that the appropriate myth is not Cinderella but Bluebeard.

KENNETH W. GRAHAM

University of Guelph

\section{Notes}

1 Mary Poovey uses Evelina to help establish the context of her exploration in The Proper Lady and the Woman Writer (Chicago: University of Chicago Press 1984), 24-6.

2 Nancy K. Miller, The Herone's Text (New York: Columbia University Press 1980)

3 Mary Jacobus, 'The Difference of View,' in Women Writing and Writing About Women, ed. Mary Jacobus (New York: Barnes \& Noble 1979), 15

4 Burney's Lord Orville acknowledges that 'credulity is the sister of innocence.' Fanny Burney, Evelina or The History of a Young Lady's Entrance into the World 
(Oxford: Oxford University Press 1982), 240. All references are to this the most accessible edition. Subsequent citations will be placed in parentheses in the text.

5 Joyce Hemlow, 'Fanny Burney and the Courtesy Books,' PMLA 65 (1950) 738

6 John Gregory, A Father's Legacy to his Daughters (Edinburgh: Strahan and Cadell 1788), 102

7 Mary Willstonecraft, A Vindication of the Rights of Woman with Strictures on Political and Moral Subjects (London: J. Johnson 1792; rpt. 1970), 216

8 Lord Chesterfield's Letters to his Son, ed. R.K. Root (London: J.M. Dent 1929; rpt. 1963), 66-7. Fanny Burney read Chesterfield's letters soon after their publication and recognized immediately their import where women are concerned. She saw them as inculcating immorality, countenancing all gentleman-like vices, advising deceit and exhorting to inconstancy.' [The Early Diary of Frances Burney, ed. A.R. Ellis (London: G. Bell 1913), I, 314.]

9 Gregory, Father's Legacy, 105-11

10 Ibid., 124

11 Some modern commentators offer a thorough analysis at the sources of Evelina's anxieties. The following emphasize the importance of birth, status and identity in the novel: Edwine Montague and Louis L. Martz, 'Fanny Burney's Evelina,' in The Age of Johnson, essays presented to Chauncey Brewster Tinker (New Haven: Yale University Press 1949) 171-81; Emily H. Patterson, 'Family and Pilgrimage Themes in Burney's Evelina,' New Rambler 18 (1977) 41-8; Edward W. Copeland, 'Money in the Novels of Fanny Burney,' Studies in the Novel 8 (1976) 24-37; and Toby Olshin, "'To whom I Most Belong": The Role of Family in Evelina,' Eighteen-Century Life 6 (1980) 29-42. Susan Staves locates Evelina's anxieties in the violence and threats of violence surrounding her: ('Evelina: or, Female difficulties,' Modern Philology 73 [1976] 368-81).

12 Fanny Burney tells the story of her birthday fire in two places: [Mme. D'Arblay], The Wanderer; or Female difficulties 5 vols. (London: Longman et al. 1814) 1, xx-xxi; Mme. D'Arblay, Memoirs of Doctor Burney. 3 vols. (London: Edward Moxon 1832; rpt. AMS Press 1975), II, 125-6.

13 Gregory, Father's Legacy, 43 et passim

14 Only one of Dr. Gregory's daughters, Dorothea, lived to maturity. At her father's death, she became a companion to the famous bluestocking, Elizabeth Montagu, and it was under these circumstances that Fanny Burney, in the company of Hester Thrale, met her. They must have discovered much to discuss as daughters of dominant and persuasive fathers, and as protegees of older women and social rivals. Miss Gregory married the Reverend Archibald Alison in 1784 and, although it appears that the two women never met again, Fanny Burney's journal entries for the next thirty years refer to her in complimentary terms like, 'my favourite Miss Gregory,' and 'the very agreeable Miss Gregory who lived with Mrs. Montagu.'

15 Gregory, Father's Legacy, 58

16 In charging Evelina with snobbishness, Lord David Cecil echoes Hazlitt in an assessment of Fanny Burney's novels that is startling in its superficiality and insensitivity. 'Fanny Burney's Novels,' Essays on the Eighteenth Century Presented to David Nichol Smith (New York: Russell and Russell 1963) 212-4. 
17 Lord Merton's comment must have stayed in Mary Wollstonecraft's mind because she partly recalls it in her introduction to the Rights of Woman when underlying the need for women to develop intellectual qualities more enduring than transient beauty: 'A lively writer, I cannot recollect his name, asks what business women turned of forty have to do in the world?' (36) Evelina seems to have played a part in the development of Wollstonecraft's recognition of the destructive effects of social restrictions on women.

18 The Early Diary of Frances Burney, ed. A.R. Ellis (London: G. Bell 1913), I, 280

19 Marilyn Butler, Romantics, Rebels and Reactionaries (Oxford: Oxford University Press 1981), 105 